\title{
A survey on the effects of aggressive marketing, price leadership and product focus on marketing channels in relationship-oriented marketing
}

\author{
Ali Ghanbarzad ${ }^{\mathrm{a}^{*}}$, Alireza Moghadasi ${ }^{\mathrm{b}}$ and Yahya Dadashkarimi ${ }^{\mathrm{c}}$
}

${ }^{a}$ Department of Management, International Branch, Islamic Azad University, Dubai, Iran ${ }^{b}$ PhD Student, Strategic Management, Supreme National Defence University, Tehran, Iran cPhD Student, Department of Management, Science \& Research Branch, Islamic Azad University, Tehran, Iran CHRON I CLE AB S T RACT

Article history:

Received July 28, 2013

Received in revised format

20 November 2013

Accepted 4 January 2014

Available online

March 42014

Keywords:

Aggressive marketing

Price leadership

Focus strategy

Relationship-oriented marketing

\begin{abstract}
In this paper, we have performed a survey to study the effects of aggressive marketing, price leadership and product focus on marketing channels in relationship-oriented marketing. The study adopts a model developed earlier by Rokkan and Haugland (2002) 「Rokkan, A. I., \& Haugland, S. A. (2002). Developing relational exchange: effectiveness and power. European Journal of Marketing, 36(1/2), 211-230.]. The study has been executed among all managers of a firm named PET Technologies. There were 30 managers working for the proposed case study of this paper and we have designed a questionnaire in Likert scale and distributed it among all managers of this firm. Cronbach alpha is calculated as 0.931, which is well above the minimum acceptable level of 0.70 . The results have confirmed that all thee marketing strategies influence on relationship-oriented marketing, positively.
\end{abstract}

\section{Introduction}

During the past few decades, there have growing competition among business owners one getting more market share and customer retention (Ford, 1980; Pillai \& Sharma, 2003a,b). Fruchter and Sigué (2005), for instance, presented an analytical model to help detect optimal decision rules for transactional and relational marketing efforts. They reported that when the seller benefits from the interaction between the transactional marketing effort and buyer's commitment, then the seller's optimal decision rules could change over time and it depends on the level of the partners' commitment. In addition, the seller's optimal decision rules for the two kinds of marketing may be constant over time. They also concluded that the seller could allocate more resources to relational marketing at the beginning of a relational exchange and, later on, ought to assign more resources to transactional marketing. Marketing theory and practice have concentrated persistently on exchange 
between buyers and sellers. Nevertheless, many of the marketing strategies treat buyer-seller exchanges as discrete events, not as ongoing relationships. Dwyer et al. (1987) presented a framework for developing buyer-seller relationships, which helps us point for formulating marketing strategy and for stimulating new research directions. Claro et al. (2005) performed an investigation on relationship marketing strategies for the events when buyer and supplier follow various strategies to achieve performance. Black and Peeples (2005) investigated the effects of a propensity for relationalism and market growth on distribution channel outcomes.

\section{The proposed study}

The proposed study of this paper performs a survey to study the effects of aggressive marketing, price leadership and product focus on marketing channels in relationship-oriented marketing. The study adopts a model developed earlier by Rokkan and Haugland (2002). Fig. 1 shows details of the proposed study.

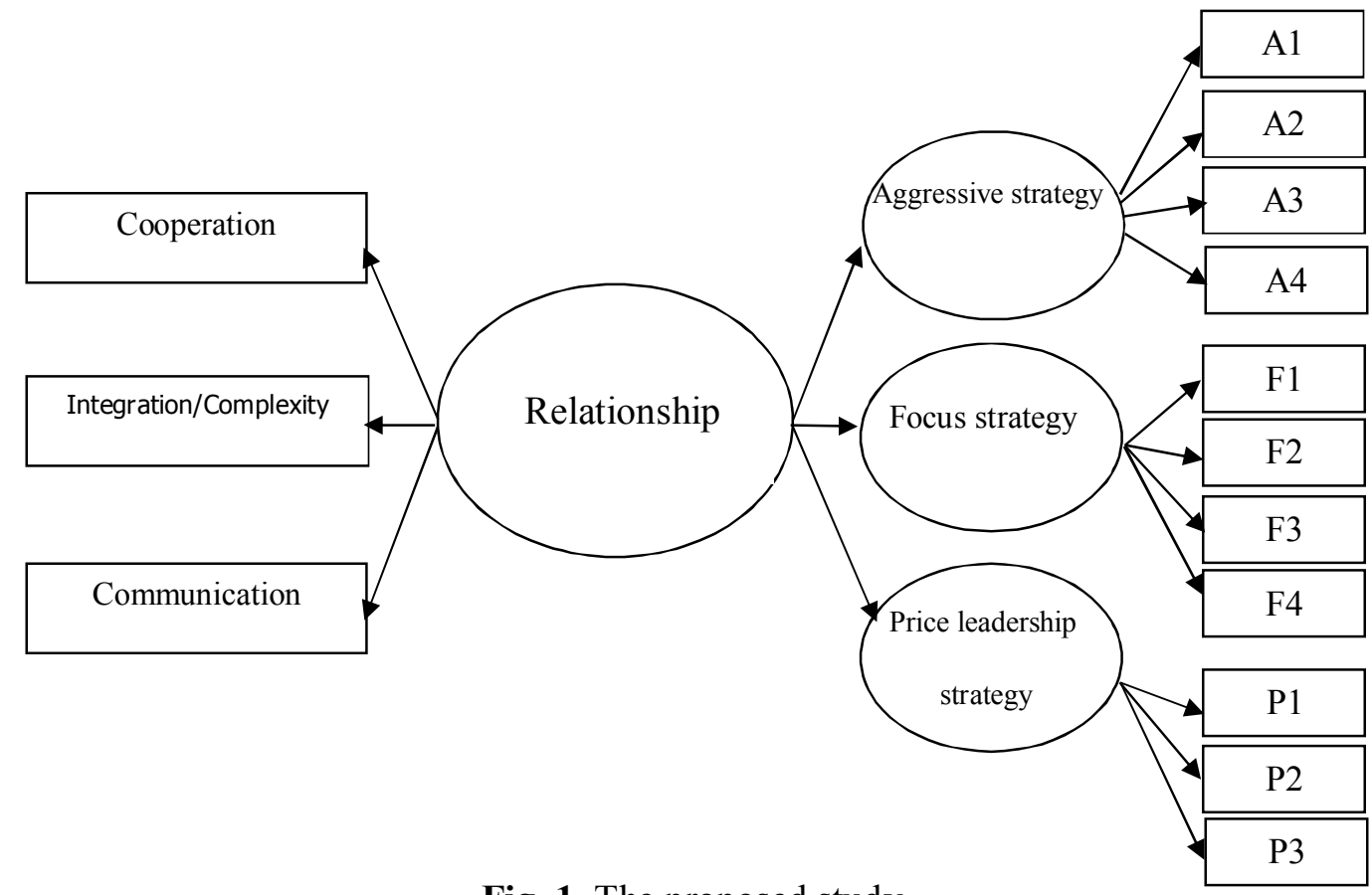

Fig. 1. The proposed study

The first strategy, aggressive strategy consists of four components including Continuous improvement of the market (A1), Emphasis on new products (A2), Active and aggressive strategy (A3) and Being responsive to rivals' actions (A4). In addition, the focus strategy includes four components including Having limited number of products (F1), Dealing with specialized products (F2), Reaching numerous products (F3) and Being specialized production plan (F4). Finally, the pricing strategy consists of three factors including Acting as leader in giving discount (P1), Not offering under price (P2) and Paying more attention on price to offer the minimum price to customer (P3). There are four hypotheses associated with the proposed study of this paper as follows,

1. There are meaningful relationships between three aggressive, focus and price leadership strategies and relationship-oriented marketing.

2. There is a relationship between aggressive leadership strategy and distribution channels in relationship-oriented marketing. 
3. There is a relationship between focus leadership strategy and distribution channels in relationship-oriented marketing.

4. There is a relationship between price leadership strategy and distribution channels in relationship-oriented marketing.

The study has been executed among all managers of a firm named PET Technologies. There were 30 managers working for the proposed case study of this paper and we have designed a questionnaire in Likert scale and distributed it among all managers of this firm. Cronbach alpha has been calculated as 0.931 , which is well above the minimum acceptable level. In our survey, $76.7 \%$ of the participants were male and $20.9 \%$ of them were female. Fig. 2 shows other personal characteristics of the participants.

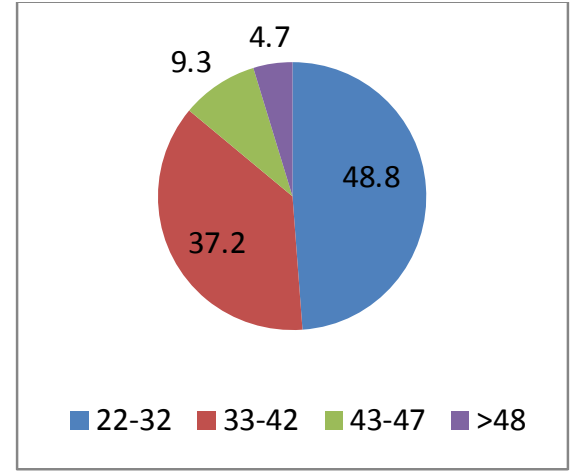

Age

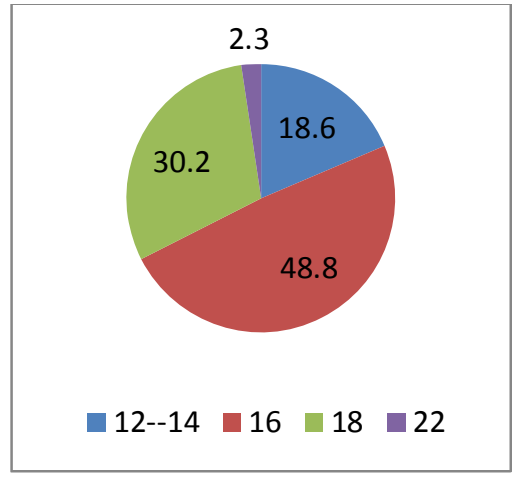

Year of education

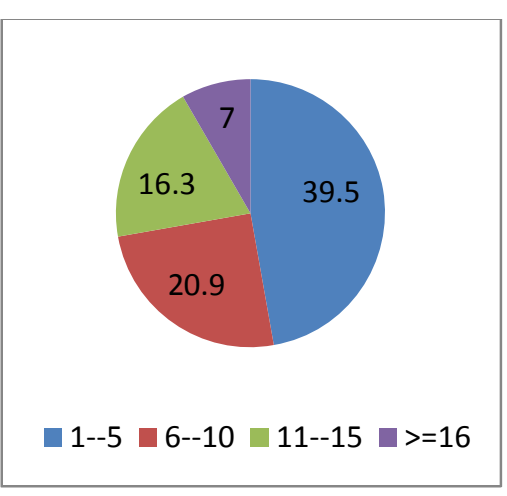

Job experience

Fig. 2. Personal characteristics of the participants

As we can observe from the results of Fig. 2, most participants in our survey are middle age and maintain at least a university education with relatively good job experiences. Next, we present details of our findings on testing various hypotheses of the survey. The proposed study uses structural equation modeling to examine different hypotheses of the survey.

\section{The results}

In this section, we present details of our investigation on testing different hypotheses of the survey. Fig. 3 shows details of the results of SEM implementation.

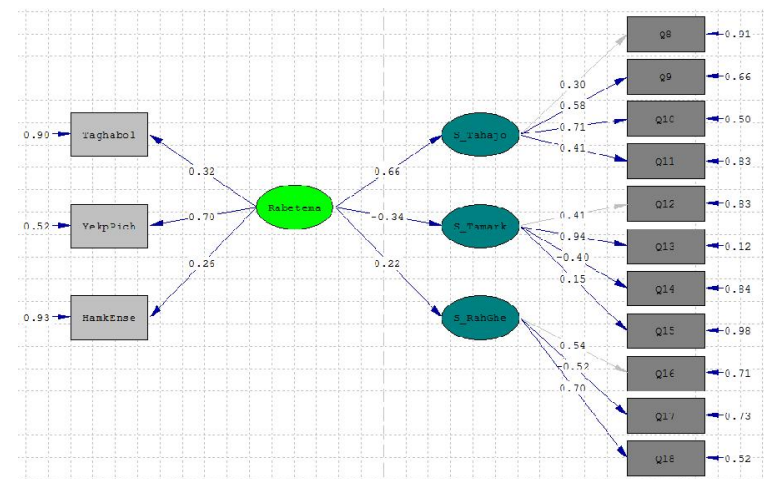

Standard coefficients

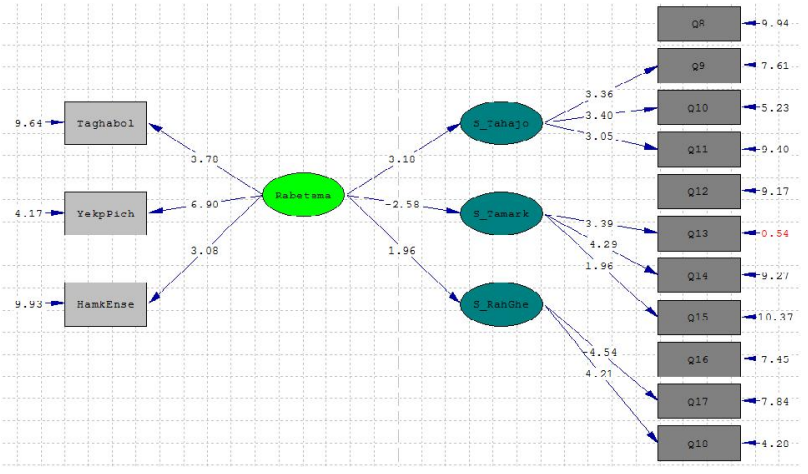

t-student values

Taghabol: Cooperation, YehpP ich: Integration, Complexity, HamkEnse: Communication, S_Tahoajo=Aggressive strategy , S_Tamark= Focus strategy, S_RahGhe: Price leadership

Fig. 3. The results of structural equation modeling

In addition, Table 1 shows details of statistical observation associated with SEM implementation. 


\section{Table 1}

The summary of statistical observations

\begin{tabular}{|c|c|c|c|c|}
\hline Attribute & Description & Acceptable range & Value & Result \\
\hline $\mathrm{X}^{2} / \mathrm{df}$ & Chi square divided to degree of freedom & $\mathrm{X}^{2} / \mathrm{df}<=3$ & 2.84 & Confirmed \\
\hline RMSEA & Root mean square error of approximation & RMSEA $<0.09$ & 0 & Confirmed \\
\hline GFI & Goodness of fit index & $\mathrm{GFI}>0.9$ & 0.92 & Confirmed \\
\hline CFI & Compression fit index & $\mathrm{CFI}>0.90$ & 0.9 & Confirmed \\
\hline IFI & Incremental fit index & IFI $>0.90$ & 0.9 & Confirmed \\
\hline RFI & Relative Fit Index & $\mathrm{NFI}>0.90$ & 0.91 & Confirmed \\
\hline
\end{tabular}

As we can observe from the results of Table 1, all statistical observations associated with SEM implementation are within acceptable limits and we can therefore rely on the results of the method.

Table 2 shows details of our results.

\section{Table 2}

The results of testing various components

\begin{tabular}{lcccccc}
\hline The effects of various factors & Standard $\beta$ & Standard error & t-value & $\mathrm{R}^{2}$ & Sig. & Result \\
\hline The effect of aggressive marketing & 0.66 & 0.21 & 3.18 & 0.44 & $\mathrm{P}<0.01$ & Confirmed \\
The effect of price leadership marketing & -0.34 & 0.13 & -2.58 & 0.12 & $\mathrm{P}<0.05$ & Confirmed \\
The effect of focus leadership marketing & 0.26 & 0.11 & 1.96 & 0.05 & $\mathrm{P}<0.05$ & Confirmed \\
\hline
\end{tabular}

Based on the results of Table 2, we can confirm all hypotheses of the survey and conclude that there are meaningful relationships between three aggressive, focus and price leadership strategies and relationship-oriented marketing.

\section{Conclusion}

In this paper, we have performed a survey to study the effects of aggressive marketing, price leadership and product focus on marketing channels in relationship-oriented marketing. The study adopts a model developed earlier by Rokkan and Haugland (2002) and the proposed study has been applied in an international firms. Using structural equation modeling the study has confirmed the effects of aggressive, price leadership as well as focus leadership on relationship-oriented marketing.

\section{References}

Black, G.S., \& Peeples, D.K. (2005). The impact of a propensity for relationalism and market growth on distribution channel outcomes. Journal of Business Strategies, 22(2), 119-34.

Claro, D. P., Claro, P. B. \& Zylbersztajn, D. (2005). Relationship marketing strategies: When buyer and supplier follow different strategies to achieve performance. Brazilian Administration Review, 2, 17-34.

Dwyer, F. R., Schurr, P. H., \& Oh, S. (1987). Developing buyer-seller relationships. The Journal of marketing, 51(2), 11-27.

Ford, D. (1980). The development of buyer-seller relationships in industrial markets. European Journal of Marketing, 14(5/6), 339-353.

Fruchter, G. E., \& Sigué, S. P. (2005). Transactions vs. relationships: what should the company emphasize?. Journal of Service Research, 8(1), 18-36.

Pillai, K. G. \& Sharma, A. (2003a). The impact of transactional and relational strategies in business markets: An agenda for inquiry. Industrial Marketing Management, 32, 623-626.

Pillai, K. G. \& Sharma, A. (2003b). Mature relationships: Why does relational orientation turn into transaction orientation?. Industrial Marketing Management, 32, 643-651.

Rokkan, A. I., \& Haugland, S. A. (2002). Developing relational exchange: effectiveness and power. European Journal of Marketing, 36(1/2), 211-230. 